\title{
Pengaruh Kualitas Produk dan Komunikasi Marketing pada Brand Image serta Dampaknya terhadap Loyalitas Pelanggan pada Produk Sarung di Surabaya
}

\author{
Pontjo Bambang ${ }^{1 *}$, Yesa Cahayaning Ramadhani ${ }^{2)}$ \\ ${ }^{\left.1,2^{*}\right)}$ Program Studi Manajemen, Fakultas Ekonomi, Sekolah Tinggi Ilmu Ekonomi Indonesia (STIESIA) \\ Surabaya, Indonesia \\ Menur Pumpungan No 30. Kecamatan Sukolilo, Kelurahan Menur Pumpungan, Kota Surabaya (60118) \\ E-mail: pontjobambang@stiesia.ac.id ${ }^{1 *}$
}

\begin{abstract}
ABSTRAK
Tujuan dari penelitian ini untuk menguji secara empiris pengaruh kualitas produk terhadap brand image konsumen, pengaruh komunikasi marketing terhadap brand image konsumen, pengaruh brand image terhadap loyalitas. Penelitian ini menggunakan sumber data primer dan sekunder yang diperoleh secara langsung dengan menyebarkan kuesioner sebanyak 100 kepada responden. Metode pengambilan sampel adalah non probabilitas dengan teknik pirposive sampling. Kriteria responden adalah laki-laki, metode penelitian menggunakan analisis SEM (Structural Equation Modeling). Temuan dari penelitian ini adalah, Hipotesis pertama yang menyatakan bahwa kualitas produk mempengaruhi brand image dan terbukti secara signifikan, Hipotesis kedua yang menyatakan bahwa komunikasi marketing mempengaruhi brand image tedak terbukti secara signifikan, Hipotesis ketiga yang menyatakan bahwa brand image mempengaruhi loyalitas pelanggan terbukti secara signifikan
\end{abstract}

Kata kunci: Kualitas Produk; Komunikasi Marketing; Brand Image; Loyalitas Pelanggan.

\begin{abstract}
The purpose of this study was to empirically examine the effect of product quality on consumer brand image, the effect of marketing communication on consumer brand image, and the effect of brand image on loyalty. This study uses primary and secondary data sources obtained directly by distributing 100 questionnaires to respondents. The sampling method is non-probability with a pirposive sampling technique. The criteria for respondents are male, the research method uses SEM (Structural Equation Modeling) analysis. The findings of this study are, The first hypothesis which states that product quality affects brand image and is proven significantly, the second hypothesis which states that marketing communication affects brand image is not proven significantly, the third hypothesis which states that brand image affects customer loyalty is proven significantly
\end{abstract}

Keyword: Product Quality, Marketing Communication, Brand Image, Customer Loyalty 


\section{PENDAHULUAN}

Perkembangan teknologi yang sangat pesat memiliki pengaruh yang besar terhadap perkembangan gaya hidup manusia. Gaya hidup masyarakat membuat kebutuhan akan produk barang maupun jasa juga selalu berubah dan disesuaikan dengan kebutuhan dan keinginan dari masyarakat dari waktu ke waktu. Indonesia adalah negara yang sebagian besar merupakan kaum muslim. Bagi beberapa orang di Indonesia beranggapan bahwa sarung gaya hidup yang penting. Sejak abad 14, sarung dibawa oleh sudagar arab dan Gujarat, sarung menjadi salah satu pakaian kehormatan dan menunjukkan nilai kesopanan yang tinggi. Sarung adalah busana yang serbaguna. Tidak hanya bisa digunakan sebagai sarana ibadah, dapat juga digunakan untuk santai, pengganti jaket, selimut, alas tidur diatas pos ronda atau untuk hal yang konyol seperti menutup wajah. Hal itu dikarenakan bentuknya yang fleksibel karena bisa dibentuk segala rupa. Bagi sebagian orang, sarung merupakan simbol status. Sama halnya dengan merek merek baju atau tas di dunia. Biasanya orang akan beranggapan bahwa individu yang memakai baju atau tas dengan merek terkenal dan berharga mahal akan dianggap bahwa individu tersebut memiliki status tinggi (Highclass). Anggapan akan hal itu berlaku juga terhadap sarung. Sarung sendiri memiliki beragam merek dan macam, dari sarung dengan kualitas tinggi (berbahan bagus, volume benang yang digunakan, keawetan, kekuatan maupun kehalusan sarung) membuat harganya menjadi tinggi dan masuk dalam kategori premium. Sesuai dengan artikel (Khadafi, 2017) pembeda harga juga ditentukan dari cara pembuatannya, ada yang pembuatan secara manual atau dengan mesin. Harga untuk sarung premium berkisar antara 500.000 (lima ratus ribu) rupiah hinggal 1.000.000 (satu juta) rupiah keatas. Sarung dengan kualitas premium ini biasa digunakan untuk acara acara formal. Sarung yang digunakan untuk keperluan sehari-hari biasanya digunakan untuk aktivitas yang lebih santai, dengan kualitas dibawah sarung premium. Biasanya harga sarung ini berkisar antara 100.000 (seratus ribu) rupiah hingga 500.000 (lima ratus ribu) rupiah. level sarung paling rendah biasanya digunakan oleh golongan kelas menengah kebawah untuk kegiatan sehari-hari yang mana bahan dari sarung ini biasanya lebih rendah sehingga terkesan sangat licin sehingga mudah sekali terlepas saat digunakan. Sarung juga beragam dari motif, warna, dan dibuat dari daerah daerah di Indonesia yang memiliki keunikan dan keunggulannya masing-masing. 
Tabel 1. Data Top 5 Merek Sarung

\begin{tabular}{ccc}
\hline Merek & TBI & TOP \\
\hline Cap gajah duduk & $39,3 \%$ & TOP \\
Atlas & $22,2 \%$ & TOP \\
Wadimor & $17,1 \%$ & TOP \\
Cap manga & $10,8 \%$ & \\
Samarinda & $2,3 \%$ & \\
\hline
\end{tabular}

Sumber Data: top brand award 2018 fase ke 2

Menurut sumber data yang didapat dari top brand award 2018 fase ke 2 didapat data bahwa ada 5 (lima) brand sarung terbaik, yaitu gajah duduk, atlas, wadimor, cap manga, dan samarinda. Data ini diperoleh berdasarkan survey di bulan mei hingga juni 2018 dan melibatkan 15 kota yang terdiri dari Jakarta, Bandung, Semarang, Jogjakarta, Surabaya, Malang, Denpasar, Medan, Samarinda, Palembang, Pekanbaru, Balikpapan, Banjarmasin, Makasar, dan Manado. Namun, dalam penelitian ini, peneliti ingin menggunakan data survey (kuesioner) kepada 100 orang konsumen sarung di Surabaya. Karena Surabaya memiliki pusat pembelanjaan sarung terbesar yaitu di daerah pasar Ampel.

Awal perkembangan sarung di Indonesia juga berubah dibandingkan dengan dulu. Perilaku konsumen juga berubah seiring dengan pergantian waktu, terbukti dengan artikel (Evergrandes, 2014) yang membuktikan bahwa adanya peningkatan atas penjualan sarung tenun di Indonesia pada tahun 2014. Meningkatnya penjualan sarung ini juga di landasi dengan keunikan cara promosi dari masing masing merek sarung itu sendiri. Sehingga konsumen lebih mengerti keunggulan dan keuntungan yang didapat jika membeli produk sarung dengan merek tertentu. Sarung awalnya diminati oleh semua orang. Biasanya digunakan untuk beribadah atau untuk menghadiri acara formal seperti pengajian, dan sebagainya. Namun, sekarang mulai tidak diminati oleh kalangan anak muda dikarenakan bagi anak muda sarung hanya untuk ibadah, kadang terlalu norak untuk dipakai di acara tertentu. Sehingga sarung mulai tidak diperhatikan. Hal ini membuat produsen sarung harus menciptakan sesuatu yang baru agar anak muda mulai tertarik kembali dengan sarung. Menurut Sugito, (2009) keunggulan teknologi dan inovasi produk merupakan hal yang harus ditingkatkan karena dapat menjadi diferensiasi dari suatu produk. Kualitas produk juga sangat diperhatikan oleh konsumen saat ini, dibuktikan dengan konsumen rela membayar dengan harga yang tinggi untuk sarung dengan kualitas premium dikarenakan kualitas produk yang lebih baik sehingga tahan lama tidak mudah rusak, walaupun perawatannya juga bisa dibilang tidak mudah. Namun kenyamanan dalam menggunakan dan 
ketahanan produk membuat brand image tersendiri bagi konsumen (Hasan, 2018). Komunikasi marketing akan produk sarung juga tidak kalah pentingnya, karena dengan menggunakan komunikasi marketing yang baik, maka akan lebih menarik perhatian konsumen. Marketing suatu produk akan menggunakan strateginya masing-masing dengan cara yang unik dan modern agar mampu menjangkau minat dan kebutuhan tidak hanya untuk kalangan bapak-bapak saja, tetapi juga menjangkau anak muda yang saat ini mulai tidak peduli dengan budaya akan memakai sarung itu sendiri (Hasan, 2018). Dengan komunikasi marketing yang unik itu akan meningkatkan image brand dari produk sarung itu sendiri, tujuan akhir dari suatu perusahaan adalah kesuksesan dalam membangun loyalitas pelanggan khususnya perusahaan yang berkecimpung dibidang fashion. Jika pelanggan mengalami keterikatan dengan produk kita, maka menaikkan kinerja keuangan dan melindungi kelangsungan perusahaan. hal ini menjadi alasan utama bagi sebuah perusahaan untuk menarik dan mempertahankan mereka untuk berlangganan kembali atau melakukan pembelian ulang produk/jasa terpilih secara konsisten dimasa yang akan datang (Salomon, 2008). Kondisi ini akan Impresi strategi pemasaran yang juga mempunyai potensi perubahan perilaku konsumen. Salah satu masyarakat Indonesia khususnya daerah Surabaya, gresik dan sekitarnya dapat dikatakan daerah agamis sehingga penggunaan sarung bukan saja hanya digunakan sebagai sarana beribadah. Sarung tetap sebagai salah satu pilihan masyarakat untuk dipakai sebagai kelengkapan berbusana setiap harinya dan sarung juga mempunyai keistimewaan dan ciri khas tersendiri bagi masyarakat daerah tersebut, sehingga dapat dikatakan bahwa loyalitas masyarakat memekai sarung tersebut dapat terwujud.

Oleh karena itu, peneliti tertarik untuk mengetahui hubungan yang terjadi antara kualitas produk dan komunikasi pemasaran dengan brand image produk sarung, sehingga peneliti menetapkan judul penelitian yaitu "Pengaruh Kualitas Produk dan Komunikasi Marketing pada Brand Image serta Dampaknya Terhadap Loyalitas Pelanggan pada Produk Sarung di Surabaya".

\section{METODE PENELITIAN}

Lingkungan generalisasi atas subyek penelitian yang mempunyai kualitas dan karakteristik tertentu yang ditetapkan oleh peneliti untuk dipelajari dan kemudian ditarik kesimpulannya itu merupakan populasi (Anshori \& Irawati, 2009). Bagian dari populasi dengan karakteristik tertentu yang ditetapkan peneliti merupakan sampel.

Pengambilan sampel dilakukan dengan pengisian data kuesioner yang ditujukan kepada 100 orang responden laki-laki di Surabaya yang merupakan pelanggan dari pasar Ampel 
Surabaya dengan rentang umur dari 20 tahun hingga 60 tahun keatas. Rentang umur tersebut merupakan strata dalam penelitian, dimana setiap responden hanya akan mewakili salah satu strata.

\section{Identifikasi Variabel}

Variabel penelitian yang dipergunakan dalam model penelitian ini dikelompokkan menjadi: Variabel bebas dan Variabel terikat.

Variabel bebas:

a. Kualitas Produk $\left(\mathrm{X}_{1}\right)$ :

$$
\begin{aligned}
& \mathrm{X}_{1.1}=\text { Technology } \\
& \mathrm{X}_{1.2}=\text { Reliability } \\
& \mathrm{X}_{1.3}=\text { Confortable } \\
& \mathrm{X}_{1.4}=\text { Product Design } \\
& \mathrm{X}_{1.5}=\text { Product Variant }
\end{aligned}
$$

b. Komunikasi Marketing $\left(\mathrm{X}_{2}\right)$

$$
\begin{aligned}
& \mathrm{X}_{2.1}=\text { Media Advertising } \\
& \mathrm{X}_{2.2}=\text { Consumer Promotion } \\
& \mathrm{X}_{2.3}=\text { Event Marketing } \\
& \mathrm{X}_{2.4}=\text { Packaging } \\
& \mathrm{X}_{2.5}=\text { Tag Line }
\end{aligned}
$$

Variabel terikat:

a) Brand Image $\left(\mathrm{Y}_{1}\right)$

$$
\begin{aligned}
& \mathrm{Y}_{1.1}=\text { Brand Awarness } \\
& \mathrm{Y}_{1.2}=\text { Brand Association } \\
& \mathrm{Y}_{1.1}=\text { Brand Identity } \\
& \mathrm{Y}_{1.1}=\text { Brand Personality }
\end{aligned}
$$

b) Loyalitas Pelanggan $\left(\mathrm{Y}_{2}\right)$

$$
\begin{aligned}
& \mathrm{Y}_{2.1}=\text { No Loyalty } \\
& \mathrm{Y}_{2.2}=\text { Latent Loyalty } \\
& \mathrm{Y}_{2.3}=\text { Inertia Loyalty } \\
& \mathrm{Y}_{2.4}=\text { Premium Loyalty }
\end{aligned}
$$


Tabel 2. Data Variabel Penelitian

\begin{tabular}{|c|c|c|c|c|}
\hline No. & Variabel & Poin & Indikator & Item \\
\hline \multirow{5}{*}{1} & \multirow{5}{*}{$\begin{array}{l}\text { Kualitas } \\
\text { produk }\left(\mathrm{X}_{1}\right)\end{array}$} & Technology & $\begin{array}{l}\text { Tingkatan teknologi pada } \\
\text { merek suatu produk }\end{array}$ & $\begin{array}{l}\text { Merek pilihan responden } \\
\text { berteknologi tinggi }\end{array}$ \\
\hline & & Reliability & $\begin{array}{l}\text { Tingkatan keandalan pada } \\
\text { merek suatu produk }\end{array}$ & $\begin{array}{l}\text { Merek pilihan responden memiliki } \\
\text { bahan berdaya serap tinggi. }\end{array}$ \\
\hline & & Comfortable & $\begin{array}{l}\text { Tingkatan kenyamanan pada } \\
\text { merek suatu produk }\end{array}$ & $\begin{array}{l}\text { Merek pilihan responden memiliki } \\
\text { tingkat kenyamanan tinggi. }\end{array}$ \\
\hline & & Product Design & $\begin{array}{l}\text { Desain pada merek suatu } \\
\text { produk }\end{array}$ & $\begin{array}{l}\text { Merek pilihan responden memiliki } \\
\text { desain yang inovatif }\end{array}$ \\
\hline & & $\begin{array}{l}\text { Product } \\
\text { Variant }\end{array}$ & $\begin{array}{l}\text { Varian pada merek suatu } \\
\text { produk }\end{array}$ & $\begin{array}{l}\text { Merek pilihan responden memiliki } \\
\text { beragam dan sesuai kebutuhan }\end{array}$ \\
\hline \multirow{5}{*}{2} & \multirow{5}{*}{$\begin{array}{l}\text { Komunikasi } \\
\text { Marketing } \\
\left(\mathrm{X}_{2}\right)\end{array}$} & $\begin{array}{c}\text { Media } \\
\text { Advertising }\end{array}$ & $\begin{array}{l}\text { Periklanan produk melalui } \\
\text { tayangan di media cetak dan } \\
\text { elektronik }\end{array}$ & $\begin{array}{l}\text { Merek pilihan responden sering } \\
\text { muncul di media cetak maupun } \\
\text { elektronik }\end{array}$ \\
\hline & & $\begin{array}{l}\text { Customer } \\
\text { Promotion }\end{array}$ & $\begin{array}{l}\text { Kegiatan promosi penjualan } \\
\text { melibatkan produk }\end{array}$ & $\begin{array}{l}\text { Merek pilihan responden giat } \\
\text { melakukan promosi penjualan }\end{array}$ \\
\hline & & $\begin{array}{c}\text { Event } \\
\text { Marketing }\end{array}$ & $\begin{array}{l}\text { Kegiatan yang disponsori oleh } \\
\text { merek produk }\end{array}$ & $\begin{array}{l}\text { Merek pilihan responden sering } \\
\text { mengadakan event menarik }\end{array}$ \\
\hline & & Packaging & $\begin{array}{l}\text { Kemasan dari merek suatu } \\
\text { produk }\end{array}$ & $\begin{array}{l}\text { Merek pilihan responden memiliki } \\
\text { kemasan yang menarik }\end{array}$ \\
\hline & & Tag Line & Slogan dari merek suatu produk & $\begin{array}{l}\text { Merek pilihan responden memiliki } \\
\text { slogan yang menarik }\end{array}$ \\
\hline \multirow{4}{*}{3} & \multirow{4}{*}{$\begin{array}{l}\text { Brand Image } \\
\qquad\left(\mathrm{Y}_{1}\right)\end{array}$} & $\begin{array}{l}\text { Brand } \\
\text { Awarness }\end{array}$ & $\begin{array}{l}\text { Kemampuan konsumen untuk } \\
\text { mengingat kembali merek suatu } \\
\text { produk }\end{array}$ & $\begin{array}{l}\text { Responden selalu teringat merek } \\
\text { pilihannya }\end{array}$ \\
\hline & & $\begin{array}{c}\text { Brand } \\
\text { Association }\end{array}$ & $\begin{array}{l}\text { Kemampuan konsumen untuk } \\
\text { membedakan suatu merek dari } \\
\text { merek yang lain }\end{array}$ & $\begin{array}{l}\text { Responden mampu membedakan } \\
\text { merek pilihannya dengan merek } \\
\text { lain }\end{array}$ \\
\hline & & Brand Identity & $\begin{array}{l}\text { Kemampuan konsumen untuk } \\
\text { menilai merek sebagai suatu } \\
\text { identitas tersendiri }\end{array}$ & $\begin{array}{l}\text { Responden menilai merek } \\
\text { pilihannya memiliki identitas } \\
\text { tersendiri }\end{array}$ \\
\hline & & $\begin{array}{l}\text { Brand } \\
\text { Personality }\end{array}$ & $\begin{array}{l}\text { Kemampuan konsumen untuk } \\
\text { menilai merek sesuai dengan } \\
\text { kepribadiannya }\end{array}$ & $\begin{array}{l}\text { Responden menilai merek } \\
\text { pilihannya sesuai dengan } \\
\text { kepribadiannya }\end{array}$ \\
\hline \multirow{4}{*}{4} & \multirow{4}{*}{$\begin{array}{l}\text { Loyalitas } \\
\text { Pelanggan } \\
\quad\left(\mathrm{Y}_{2}\right)\end{array}$} & No Loyalty & $\begin{array}{l}\text { Komitmen konsumen untuk } \\
\text { mencoba merek lain }\end{array}$ & $\begin{array}{l}\text { Responden tertarik untuk mencoba } \\
\text { merek lain, walaupun sudah puas } \\
\text { dengan merek pilihannya }\end{array}$ \\
\hline & & Latent Loyalty & $\begin{array}{l}\text { Komitmen konsumen mengenai } \\
\text { alternative pilihan merek }\end{array}$ & $\begin{array}{l}\text { Responden mencari alternative } \\
\text { merek lain jika merek pilihannya } \\
\text { tidak ada }\end{array}$ \\
\hline & & Inertia Loyalti & $\begin{array}{l}\text { Komitmen konsumen untuk } \\
\text { kembali menggunakan suatu } \\
\text { merek produk }\end{array}$ & $\begin{array}{l}\text { Responden selalu menggunakan } \\
\text { merek pilihannya }\end{array}$ \\
\hline & & $\begin{array}{l}\text { Premium } \\
\text { Loyalti }\end{array}$ & $\begin{array}{l}\text { Komitmen konsumen sebagai } \\
\text { media word of mouth }\end{array}$ & $\begin{array}{l}\text { Responden akan } \\
\text { merekomendasikan merek } \\
\text { pilihannya kepada orang lain }\end{array}$ \\
\hline
\end{tabular}

Sumber: data diolah peneliti 


\section{Jenis dan Sumber Data}

Penelitian ini dilakukan dengan menggunakan data primer dan sekunder. Data yang langsung diperoleh sumber data pertama di lokasi penelitian disebut data primer. Dalam penelitian ini data primer berupa data kuantitatif diperoleh dari pengisian kuesioner oleh responden dan data kualitatif dari wawancara singkat.

Data sekunder adalah data yang didapatkan dari pihak lain dan bukan dari perusahaan secara langsung. Jenis data yang digunakan dalam penelitian ini adalah literature-literatur karya tulis, buku, dam artikel yang berkompeten dalam bidang manajemen pemasaran. Selain itu, data juga diperoleh dari sejumlah situs online yang membahas tentang produk sarung.

\section{Analisis Data Kualitatif}

Data kualitatif dalam penelitian ini yaitu dengan menyertakan pertanyaan-pertanyaan tertulis yang mendeskripsikan pendapat responden mengenai produk sarung yang dapat mempengaruhi brand image serta dampaknya terhadap loyalitas konsumen.

\section{Analisis Data Kuantitatif}

Data kuantitatif bersifat deskriptif bertujuan untuk menjelaskan, meringkas berbagai kondisi, situasi, dan berbagai variabel yang menjadi objek penelitian berdasarkan apa yang terjadi (Bungin, 2011). Peneliti menggunakan program SPSS sebagai perhitungan data kuesioner dan program AMOS untuk mendapatkan hasil perhitungan yang menggunakan metode SEM (Structural Equation Modeling). SEM menurut (Augusty, 2005) yaitu model tentang struktur hubungan yang membentuk atau menjelaskan kausalitas antara faktor.

\section{Lokasi penelitian}

Lokasi penelitian ini, mengambil kuesioner pada 100 orang responden dari pelanggan produk sarung di pasar Ampel Surabaya.

\section{Prosedur Pengumpulan Data}

Prosedur data yang dirancang oleh peneliti untuk menggambarkan tata cara dalam mengumpulkan data adalah sebagai berikut: Pertama membagikan kuesioner kepada sejumlah responden laki-laki, kedua menjelaskan tata cara pengisian kuesioner, ketiga mengumpulkan dan melakukan seleksi atas kuesioner yang telah diisi, memindahkan dan mengolah data hasil dari kuesioner untuk selanjutnya dapat di lakukan perhitungan analisis melalui program SPSS dan AMOS.

Pontjo Bambang dan Yesa Cahayaning Ramadhani: Pengaruh Kualitas Produk dan Komunikasi Marketing pada Brand Imange 
Skala likert ini dipergunakan dalam penelitian ini untuk menganalisis kuesioner yang dipergunakan untuk mengukur sikap, pendapat konsumen tentang sesuatu permasalahan akan kejadian tertentu, dengan skala skor penilaian dari 1 sampai 5 sebagai berikut (Hasan, 2018):

1. Pilihan jawaban 5 berarti Sangat Setuju

2. Pilihan jawaban 4 berarti Setuju

3. Pilihan jawaban 3 berarti Cukup Setuju

4. Pilihan jawaban 2 berarti Tidak Setuju

5. Pilihan jawaban 1 berarti Sangat Tidak Setuju

\section{Pengembangan Model Teoritis}

Langkah awal dalam ekspansi proses pencarian suatu model yang memiliki justifikasi teoritis yang kuat, setelah itu model divalidasi secara empirik melalui program SEM dinamakan model SEM

\section{Pengembangan Diagram Alur (path diagram)}

Pada tahap model teoritis dilakukan dengan mengambarkan diagram sehingga mempermudah hubungan kausalitas yang diujinya dan dinyatakan dalam bentuk persamaan, tersebut digambarkan dalam sebuah path diagram. Di dalam SEM peneliti bekerja dengan construct atau factor yaitu konsep yang mempunyai pijakan teoritis yang cukup untuk menjelaskan berbagai bentuk hubungan

(1). Variabel yang tidak dapat diprediksi oleh variabel lain dalam model dan konstruk yang dituju oleh garis dengan satu anah panah disebut source variable atau independent variable atau Konstruk eksogen (exegenous constructs). (2). Konstruk endogen (endogenous constructs). Konstruk endogen adalah faktor-faktor yang diprediksi oleh satau atau beberapa konstruk. Konstruk ini dapat memprediksi satu atau beberapa konstruk lainnya, tetapi konstruk eksogen hanya dapat berhubungan kausal dengan konstruk endogen. (3). Konversi diagram alur ke dalam persamaan. konversi ini dapat digunakan untuk mengkorversi spesifikasi model ke dalam rangkaian persamaan, persamaan tersebut adalah:

Variabel Endogen $=$ variabel eksogen + variabel endogen + error

Sehingga didalam penelitian dapat dirumuskan persamaan structural sebagai berikut:

$$
\begin{aligned}
& \mathrm{Y} 1=\beta_{1} \mathrm{X}_{1}+\beta_{2} \mathrm{X}_{2}+\delta_{1} \\
& \mathrm{Y} 2=\beta_{1} \mathrm{Y}_{1}+\delta_{1}
\end{aligned}
$$

Pontjo Bambang dan Yesa Cahayaning Ramadhani: Pengaruh Kualitas Produk dan Komunikasi Marketing pada Brand Imange 
Dimana:

$\beta=$ Regression Weight

$\delta=$ Disturbance Term (gangguan)

(1) Evaluasi kriteria Goodness of Fit

Kesesuaian model dievaluasi melalui tahapan Goodnes of Fit, yaitu mengevaluasi apakah data digunakan memenuhi asumsi SEM, adalah sebagai berikut:

\section{Ukuran sampel}

Ukuran sampel yang harus dipenuhi dalam model ini adalah minimum berjumlah 100 dan selanjutnya menggunakan perbandingan 5 observasi untuk setiap estimated parameter.

\section{Normalitas dan linieritas}

Uji normalitas untuk data tunggal maupun multivariat dimana beberapa variabel digunakan sekaligus dalam analisis akhir.sedangkan uji linieritas dapat dilakukan dengan memilih pasangan data dan pola penyebarannya untuk menduga ada tidaknya linieritas.

\section{Outliers}

Outlier adalah suatu observasi yang muncul dengan nilai ekstrim baik secara univariat maupun multivariat yaitu yang muncul karena kombinasi karakteristik unik yang dimilikinya.

\section{Multicollinierity dan Singularity}

Multikolinieritas dapat digunakan untuk menditeksi dari determinan matrik kovarian. Nilai ini sangat kecil (extremely small) memberikan indikasi adanya problem multikolinieritas atau singularitas.

Tabel dibawah ini menunjukkan kriteria untuk mengevaluasi model dan pengaruh sesuai uji kesesuaian dan uji statistik.

Tabel 3. Goodness of Fit Index

\begin{tabular}{|c|c|}
\hline Goodness of Fit Index & Cut-Off Value \\
\hline Chi-square & Diharapkan kecil \\
\hline Significance Probability & $\geq 0,05$ \\
\hline RMSEA & $\leq 0,08$ \\
\hline GFI & $\geq 0,90$ \\
\hline AGFI & $\geq 0,90$ \\
\hline CMIN/DF & $\leq 2,00$ \\
\hline TLI & $\geq 0,95$ \\
\hline CFI & $\geq 0,95$ \\
\hline
\end{tabular}

Sumber: Augusty $(2005,282)$

Pontjo Bambang dan Yesa Cahayaning Ramadhani: Pengaruh Kualitas Produk dan Komunikasi Marketing pada Brand Imange 


\section{Pengujian Validitas}

Instrumen itu valid, jika instrumen tersebut dapat dipergunakan untuk mengukur apa yang seharusnya diukur dan proses Pengujian dapat dilakukan dengan prosedur membandingkan antara $\mathrm{r}$ hitung dan $\mathrm{r}$ kritis. Jika $\mathrm{r}$ hitung $>$ dari $\mathrm{r}$ kritis dan meiliki nilai positif, maka pernyataan pada tiap variabel dapat dikatakan valid. Nilai r kritis yang dipakai adalah 0,30 (Sugiyono, 207:109)

\section{Pengujian Reliabilitas}

Pengujian ini untuk memastikan bahwa variabel-variabel penelitian dapat dipercaya dan dapat diandalkan sehingga butir-butir pertanyaan dalam penelitian memiliki konsistensi dari waktu ke waktu. Dianggap reliabel jika nilai alpha cronbach di atas 0,6 (Ghozali, 2006:41).

\section{Uji Hipotesis}

Uji hipotesis menurut (Augusty, 2005) ada 2 (dua) kelompok hipotesis statistik, yaitu: pengujian hipotesis model dan pengujian hipotesis kausalitas.

\section{Pengujian Hipotesis Model}

Pengujian ini dinyatakan dnegan hipotesis sebagai berikut:

$\mathrm{H}_{0}$ : Tidak ada perbedaan antara kovarian data sampel yang dikalkulasikan dengan matriks kovarians populasi estimasi.

Ha: Ada perbedaan antara kovarian data sampel yang dikalkulasikan dengan matriks kovarians populasi estimasi.

Perbedaan $\mathrm{H}_{0}$ dan $\mathrm{Ha}$ yaitu $\mathrm{Ha}$ mengaharapkan adanya kegagalan menolak hipotesis nol, sehingga Ha tidak bisa diterima, oleh karena itu $\mathrm{H}_{0}$ dianggap benar.

\section{Pengujian Hipotesis Kausalitas}

Penggujian ini menggunakan uji-t untuk melihat signifikasi koefisien regresi yang dihasilkan oleh berbagai hubungan kausalitas dalam model. Model pengujian dalam penelitian ini adalah:

$$
\begin{aligned}
& H_{0}=\beta_{1}=0 \\
& H_{a}=\beta_{1} \neq 0
\end{aligned}
$$

Signifikasi koefisien regresi dihitung dengan uji-t atau dalam AMOS disebut uji Critical Ratio (CR) dengan rumus (Augusty, 2005) sebagai berikut:

$\mathbf{C R}=\frac{\text { Estimate }}{\text { Standar Error of Estimate }} \geq \mathbf{2}$ 


\section{HASIL DAN PEMBAHASAN}

Penelitian menggunakan 100 orang responden di Surabaya, dan dilakukan pada responden yang mengunakan merek sarung pilihan responden. Proses pengumpulan data melalui penyebaran kuesioner dalam bulan april 2019 data umum hasil penelitian dapat dikelompokkan seperti yang tersaji berikut ini:

\section{Tabel 4. Klasifikasi Data Menurut Usia}

\begin{tabular}{ccc}
\hline Usia & Jumlah & Persentase \\
\hline $21-30$ tahun & 16 & 16 \\
$31-40$ tahun & 28 & 28 \\
$41-50$ tahun & 27 & 27 \\
$51-60$ tahun & 25 & 25 \\
$>60$ tahun & 4 & \\
Total & 100 &
\end{tabular}

Sumber: Kuesioner Responden (2019)

Berdasarkan Tabel 4 terlihat bahwa responden dengan usia 31 sampai 40 tahun yang paling dominan dalam penelitian ini yaitu sebanyak 28\% (28 responden, sedangkan sisanya usia 41 sampai 50 tahun sebesar 27\% (27 responden), diikuti oleh usia 51 sampai dengan 60 tahun sebesar 25\% (25 responden) dan usia 21 sampai 30 tahun sebesar 16\% (16 responden).

Tabel 5. Klasifikasi Kegiatan Responden Sehari-Hari

\begin{tabular}{lcc}
\hline \multicolumn{1}{c}{ Kegiatan } & Jumlah & Persentase \\
\hline Bekerja & 86 & 86 \\
Tidak Bekerja & 14 & 14 \\
& 100 & \\
\hline
\end{tabular}

Sumber: Kuesioner Responden (2019)

Berdasarkan Tabel 5 terlihat bahwa responden dengan kegiatan bekerja yang paling dominan dalam penelitian ini yaitu sebanyak $86 \%$ (86 responden), diikuti tidak bekerja sebesar $14 \%$ (14 responden).

Tabel 6. Klasifikasi Responden Memperoleh Informasi Produk Serta Merek

\begin{tabular}{lcc}
\hline \multicolumn{1}{c}{ Sumber Informasi } & Jumlah & Persentase \\
\hline Keluarga & 56 & 56 \\
Teman & 27 & 27 \\
Iklan di Media & 17 & 17 \\
& 100 & \\
\hline
\end{tabular}

Sumber: Kuesioner Responden (2019)

Berdasarkan Tabel 6 terlihat bahwa responden memperoleh informasi dari keluarga yang paling dominan dalam penelitian ini yaitu sebanyak 56\% (56 responden), diikuti informasi dari 
teman sebesar 27\% (27 responden) dan informasi dari Iklan di media sebesar 17\% (17 responden).

\section{Tabel 7. Klasifikasi Penggunaan Merek Sarung Pilihan Responden}

\begin{tabular}{lcc}
\hline \multicolumn{1}{c}{ Merek Sarung } & Jumlah & Persentase \\
\hline Gajah Duduk & 39 & 39 \\
Atlas & 22 & 22 \\
Wadimor & 18 & 18 \\
Cap Mangga & 12 & 12 \\
Samarinda & 9 & 9 \\
\hline
\end{tabular}

Sumber: Kuesioner Responden (2019)

Berdasarkan Tabel 7 terlihat bahwa responden menggunakan merek sarung Gajah Duduk yang paling dominan dalam penelitian ini yaitu sebanyak 39\% (39 responden) diikuti oleh merek Atlas sebesar 22\% (22 responden), dilanjutkan oleh merek Wadimor sebesar 18\% (18 responden), merek Cap Mangga sebesar 12\% (12 responden) dan merek Samarinda sebesar 9\% (9 responden).

Tabel 8. Klasifikasi Berdasarkan Alasan Menggunakan Merek Sarung Pilihan Responden

\begin{tabular}{lcc}
\hline \multicolumn{1}{c}{ Alasan menggunakan merek Sarung } & Jumlah & Persentase \\
\hline Harga terjangkau & 6 & 6 \\
Nyaman di pakainya & 54 & 54 \\
Motifnya bagus dan banyak & 15 & 15 \\
Tidak mudah kusut & 10 & 10 \\
Awet dipakainya & 15 & 15 \\
\hline
\end{tabular}

Sumber: Kuesioner Responden (2019)

Berdasarkan Tabel 8 terlihat bahwa alasan responden menggunakan merek sarung yang paling dominan dalam penelitian ini yaitu nyaman dipakainya sebanyak 54\% (54 responden) dan yang paling rendah sebesar 6\% (6 responden) adalah harga terjangkau.

Tabel 9. Klasifikasi Jenis Kemasan Sarung Yang Dipilih

\begin{tabular}{lcc}
\hline \multicolumn{1}{c}{ Jenis Kemasan Sarung } & Jumlah & Presentase \\
\hline Tanpa Kemasan & 18 & 18 \\
Plastik Bening & 20 & 20 \\
Mika Bening & 34 & 34 \\
Kotak Kardus & 28 & 28 \\
\hline
\end{tabular}

Sumber: Kuesioner Responden (2019)

Berdasarkan Tabel 9 terlihat bahwa alasan responden memilih kemasan sarung yang paling dominan dalam penelitian ini yaitu menggunakan mika sebanyak 34\% (34 responden) dan 
yang paling rendah tanpa kemasan sebesar 18\% (18 responden).

Tabel 10. Klasifikasi Media Periklanan Yang Sering Menampilkan Sarung

\begin{tabular}{lccc}
\hline & Media periklanan & Jumlah & Persentase \\
\hline Majalah & 5 & 5 \\
Televisi & 54 & 54 \\
Radio & 26 & 26 \\
Network & 15 & 15 \\
\hline
\end{tabular}

Sumber: Kuesioner Responden (2019)

Berdasarkan Tabel 10 terlihat bahwa alasan responden memilih Periklanan yang sering menampilkan merek sarung yang paling dominan dalam penelitian ini yaitu media televiasi sebanyak 54\% (54 responden) dan yang paling rendah majalah sebesar 5\% (5 responden).

\section{Deskripsi Variabel Penelitian}

Mendiskripsikan penilaian responden terhadap keempat variabel didalam penelitian, yang membedakan atas variabel bebas (brand iamge dan loyalitas pelanggan). Terdapat juga standar deviasi (standar deviation) dan mean dari responden. Menurut (Bungin, 2011), bahwa standar deviasi adalah alat untuk mendeskripsikan variabel dalam suatu distribusi maupun beberapa distribusi. Menurut (Kuncoro, 2010) standar deviasi mempunyai nilai relatif besar adalah data yang digunakan memiliki variabelitas yang tinggi. Bilai nilai standar deviasi relatif kecil, maka data yang digunakan mengelompok di seputar nilai rata-ratanya dan nilai penyimpangannya kecil.

\section{Deskripsi Variabel Kualitas Produk}

Variabel kualitas produk (X1) mempunyai lima indikator atau pertanyaan yaitu technology (X1.1), reliability (X1.2), confortable (X1.3), product design (X1.4), dan product variant (X1.5) (Kuncoro, 2010). Beberapa penilaian responden terhadap variabel kualitas produk terlihat pada tabel 11

Tabel 11. Penilaian Responden terhadap Variabel X1

\begin{tabular}{ccccc}
\hline Indikator & Minimum & Maksimum & Mean & Standar Deviasi \\
\hline X1.1 & 3 & 5 & 3,93 & 0,671 \\
X1.2 & 3 & 5 & 4,09 & 0,712 \\
X1.3 & 3 & 5 & 4,10 & 0,628 \\
X1.4 & 3 & 5 & 3,88 & 0,700 \\
X1.5 & 3 & 5 & 4,04 & 0,665
\end{tabular}

Sumber: Data Olahan

Indikator confortable (X1.3) mempunyai mean tertinggi yaitu 4,10. Hal ini mengindikasikan bahwa responden menilai kualitas produk suatu merek sarung ditandai dengan 
tingkat kenyamanan yang tinggi. Rata-rata dari mean keseluruhan adalah 4,008 yang berarti responden mempunyai penilaian yang kuat akan kualitas produk sarung.

Nilai standar deviasi dari tiap indikator menunjukkan penyimpangan yang kecil (nilai diantara 0,628 sampai 0,712) sehingga data akan mengelompok disekitar nilai rata-ratanya.

\section{Deskripsi Variabel Komunikasi Marketing}

Variabel komunikasi marketing (X2) mempunyai lima indikator yaitu media advertising (X2.1), consumer promotion (X2.2), even marketing (2.3), packaging (X2,4) dan tag line (X2.5). (kuncoro, 2010). Penilaian responden terhadap variabel komunikasi marketing terdapat pada Tabel 12.

Tabel 12. Penilaian Responden terhadap Variabel X2

\begin{tabular}{ccccc}
\hline Indikator & Minimum & Maksimum & Mean & Standar Deviasi \\
\hline X2.1 & 3 & 5 & 3,82 & 0,672 \\
X2.2 & 3 & 5 & 3,61 & 0,650 \\
X2.3 & 3 & 5 & 3,45 & 0,626 \\
X2.4 & 3 & 5 & 3,62 & 0,632 \\
X2.5 & 3 & 5 & 3,64 & 0,595 \\
\hline
\end{tabular}

Sumber: Data diolah

Media advertising (X2.1) menunjukkan bahwa nilai mean tertinggi yaitu 3,82. Hal ini mengartikan bahwa responden menilai komunikasi marketing suatu merek sarung cenderung melalui media periklanan, baik media cetak maupun elektronik. Rata-rata dari mean adalah 3,628 yang dapat diartikan bahwa responden memiliki penilaian yang cukup kuat akan komunikasi marketing terhadap produk sarung. Nilai standar deviasi dari tiap indikator menunjukkan data atau penyimpangan yang kecil (nilai berkisar 0,595 hingga 0,672), sehingga data akan mengelompok disekitar rata-ratanya.

Tabel 13. Penilaian Responden terhadap Variabel Y1

\begin{tabular}{ccccc}
\hline Indikator & Minimum & Maksimum & Mean & Standar Deviasi \\
\hline Y1.1 & 2 & 5 & 4,20 & 0,651 \\
Y1.2 & 3 & 5 & 4,08 & 0,706 \\
Y1.3 & 3 & 5 & 4,07 & 0,700 \\
Y1.4 & 3 & 5 & 4,12 & 0,624 \\
\hline
\end{tabular}

Sumber: Data diolah

\section{Deskripsi Variabel Brand Image}

Variabel brand image (Y1) mempunyai empat indikator yaitu brand awarness (Y1.1), brand association (Y1.2), brand identity (Y1.3), dan brand personality (Y1.4). (kuncoro, 2010). Penilaian responden terhadap variabel brand image terlihat pada Tabel 13. 
Indikator brand awareness (Y1.1) menunjukkan bahwa mean tertinggi yaitu 4,20. Hal ini menunjukkan bahwa brand image suatu merek sarung ditandai dengan kemudahan untuk diingat oleh responden. Rata-rata dari mean keseluruhan indikator brand image adalah 4,117 yang berarti bahwa suatu merek sarung menciptakan brand image yang kuat di benak responden.

Nilai standar deviasi dari tiap indikator menunjukkan data penelitian memiliki variabilitas atau penyimpangan yang kecil (nilai antara 0,624 sampai 0,706), sehingga data akan mengelompok diseputar nilai rata-ratanya.

\section{Deskripsi Variabel Loyalitas Pelanggan}

Variabel loyalitas pelanggan (Y2) mempunyai empat indikator yaitu royality (Y2.1), laten loyality (Y2.2), inertia loyality (Y2.3), dan premium loyality (Y2.4), (kuncoro, 2010). Penilaian responden terhadap variabel loyalitas pelanggan terlihat pada Tabel 14

\section{Tabel 14. Penilaian Responden terhadap Variabel Y2}

\begin{tabular}{ccccc}
\hline Indikator & Minimum & Maksimum & Mean & Standar Deviasi \\
\hline Y2.1 & 3 & 5 & 3,70 & 0,674 \\
Y2.2 & 3 & 5 & 4,03 & 0,703 \\
Y2.3 & 3 & 5 & 4,04 & 0,618 \\
Y2.4 & 3 & 5 & 3,97 & 0,717 \\
\hline
\end{tabular}

Sumber: Data diolah

Indikator inertia loyality (Y2.3) mempunyai mean tertinggi yaitu 4,04. Hal ini menunjukkan bahwa responden selalu menggunakan merek sarung pilihannya. Rata-rata mean keseluruhan loyalitas pelanggan adalah 3,935 yang diartikan responden cenderung untuk loyal terhadap produk sarung.

Nilai standar deviasi dari tiap indikator menunjukkan data penyimpangan yang kecil (nilai antara 0,618 sampai 0,717 ), sehingga data akan mengelompok diseputar nilai rata-ratanya.

\section{Validitas dan Reliabilitas Penelitian}

\section{Validitas Variabel}

Dikatakan valid jika butir-butir pertanyaan pada kuesioner mampu menganalisis sesuatu yang akan diukur. Pengujian dengan cara membandingkan antara $r$ hitung dengan $r$ kritis. Jika $r$ hitung (corrected Item Total Correlation) lebih besar dari r kritis dan mempunyai nilai positif, maka pertanyaan pada tiap-tiap variabel dapat dikatakan valid. Dengan nilai $\mathrm{r}$ kritis $=0.30$ (Hasan, 2018). Hasil uji validasi dari tiap-tiap variabel dapat dilihat pada Tabel 15. 
Tabel 15. Hasil Uji Validitas Variabel Kualitas Produk (X1)

\begin{tabular}{cccc}
\hline Indikator & $\begin{array}{c}\text { Corrected Item-Total } \\
\text { Correlation }\end{array}$ & r Kritis & Keterangan \\
\hline X1.1 & 0,768 & 0,3 & Valid \\
X1.2 & 0,763 & 0,3 & Valid \\
X1.3 & 0,757 & 0,3 & Valid \\
X1.4 & 0,802 & 0,3 & Valid \\
X1.5 & 0,674 & 0,3 & Valid \\
\hline
\end{tabular}

Sumber: Olahan data

Berdasarkan Tabel 15 diperoleh hasil keseluruhan indikator pada variabel kualitas produk memiliki nilai $\mathrm{r}$ hitung lebih besar dari t kritis. Maka hasil uji validitas terhadap variabel kualitas produk sesuai untuk digunakan sebagai alat ukur.

Tabel 16. Hasil Uji Validitas Variabel Komunikasi Marketing (X2)

\begin{tabular}{cccc}
\hline Indikator & Corrected Item-Total Correlation & r Kritis & Keterangan \\
\hline X2.1 & 0,630 & 0,3 & Valid \\
X2.2 & 0,639 & 0,3 & Valid \\
X2.3 & 0,654 & 0,3 & Valid \\
X2.4 & 0,579 & 0,3 & Valid \\
X2.5 & 0,575 & 0,3 & Valid \\
\hline
\end{tabular}

Sumber: Olahan data

Berdasarkan Tabel 16 diperoleh hasil keseluruhan indikator pada variabel komunikasi marketing memiliki nilai $\mathrm{r}$ hitung lebih besar dari $\mathrm{t}$ kritis. Maka hasil uji validitas terhadap variabel komunikasi marketing sesuai untuk digunakan sebagai alat ukur.

Tabel 17. Hasil Uji Validitas Variabel Brand Image (Y1)

\begin{tabular}{cccc}
\hline Indikator & Corrected Item-Total Correlation & r Kritis & Keterangan \\
\hline Y1.1 & 0,571 & 0,3 & Valid \\
Y1.2 & 0,699 & 0,3 & Valid \\
Y1.3 & 0,662 & 0,3 & Valid \\
Y1.4 & 0,652 & 0,3 & Valid \\
\hline
\end{tabular}

Sumber: Olahan data

Berdasarkan Tabel 17 diperoleh hasil keseluruhan indikator pada variabel brand image memiliki nilai $r$ hitung lebih besar dari t kritis. Maka hasil uji validitas terhadap variabel brand image sesuai untuk digunakan sebagai alat ukur. 
Tabel 18. Hasil Uji Validitas Variabel Loyalitas Pelanggan (Y2)

\begin{tabular}{cccc}
\hline Indikator & Corrected Item-Total Correlation & r Kritis & Keterangan \\
\hline Y2.1 & 0,615 & 0,3 & Valid \\
Y2.2 & 0,602 & 0,3 & Valid \\
Y2.3 & 0,485 & 0,3 & Valid \\
Y2.4 & 0,608 & 0,3 & Valid \\
\hline
\end{tabular}

Sumber: Olahan data

Berdasarkan Tabel 18 diperoleh hasil keseluruhan indikator pada variabel loyalitas pelanggan memiliki nilai $r$ hitung lebih besar dari t kritis. Maka hasil uji validitas terhadap variabel loyalitas pelanggan sesuai untuk digunakan sebagai alat ukur.

\section{RELIABILITAS VARIABEL}

Suatu variabel dapat dikatakan reliabel apabila nilai alpha cronbach diatas 0.6 (Ghozali, 2013). Hasil uji reliabilitas dapat dilihat pada Tabel 19

\section{Tabel 19. Hasil Uji Reliabilitas Variabel Penelitian}

\begin{tabular}{cccc}
\hline Indikator & Cronbach's Alpha & Alpha & Keterangan \\
\hline X1 & 0,900 & 0,6 & Reliabel \\
X2 & 0,822 & 0,6 & Reliabel \\
Y1 & 0,822 & 0,6 & Reliabel \\
Y2 & 0,774 & 0,6 & Reliabel \\
\hline
\end{tabular}

Sumber: Olahan data

Berdasarkan Tabel 19 diperoleh hasil seluruh variabel yang digunakan dalam penelitian ini mempunyai nilai Cronbach Alpha diatas nilai batas alpha sebesar 0.6. dengan demikian hasil uji reliabilitas mengindikasikan bahwa seluruh variabel adalah reliabel atau konsisten dan dapat diandalkan.

\section{Evaluasi Asumsi-asumsi SEM}

Di dalam Structural Equetion Modeling (SEM) yang hasrus dipenuhi adalah prosedur pengumpulan dan pengolahan data yang dianalisis dengan pemodelan SEM (Augusty, 2005).

\section{Evaluasi Atas Normalitas Data}

Menggunakan "Maximum Likelihood Estimation Technique” untuk mempersyaratkan dipenuhinya asumsi normalitas. Untuk menguji normalitas dengan "skewness value" dari data yang ada dan biasanya disajikan dalam statistik deskriptif. Data dapat dikatakan berdistribusi normal jika nilai kritis (critical ratio) berada pada range $\pm 2,58$ yang artinya menolak asumsi normalitas dan distribusi pada tingkat $0,01(1 \%)$.

Berdasarkan uji normalitas dengan menggunakan aplikasi AMOS menunjukkan bahwa 
nilai "critical ratio skewness value" berada pada range - 2,58 sampai + 2,58 (hasil dapat dilihat pada Tabel 20. begitu pula dengan critical ratio multivariat yang mempunyai nilai - 1, 009 yang berarti berada pada range $\pm 2,58$

Tabel 20. Assessment Of Normality

\begin{tabular}{lrrrrrr}
\hline Variable & min & max & skew & c.r. & kurtosis & c.r. \\
\hline y24 & 3,000 & 5,000 &, 044 &, 178 & $-1,036$ & $-2,114$ \\
y23 & 3,000 & 5,000 &,- 024 &,- 096 &,- 365 &,- 746 \\
y22 & 3,000 & 5,000 &,- 041 &,- 168 &,- 956 & $-1,951$ \\
y21 & 3,000 & 5,000 &, 437 & 1,785 &,- 791 & $-1,615$ \\
y14 & 3,000 & 5,000 &,- 086 &,- 350 &,- 469 &,- 957 \\
y13 & 3,000 & 5,000 &,- 095 &,- 389 &,- 940 & $-1,919$ \\
y12 & 3,000 & 5,000 &,- 112 &,- 459 &,- 975 & $-1,989$ \\
y11 & 2,000 & 5,000 &,- 441 & $-1,800$ &, 252 &, 514 \\
x25 & 3,000 & 5,000 &, 314 & 1,281 &,- 683 & $-1,395$ \\
x24 & 3,000 & 5,000 &, 506 & 2,065 &,- 650 & $-1,328$ \\
x23 & 3,000 & 5,000 &, 580 & 2,328 &, 649 & 1,100 \\
x22 & 3,000 & 5,000 &, 586 & 2,392 &,- 639 & $-1,304$ \\
x21 & 3,000 & 5,000 &, 226 &, 921 &,- 801 & $-1,635$ \\
x15 & 3,000 & 5,000 &,- 044 &,- 178 &,- 722 & $-1,474$ \\
x14 & 3,000 & 5,000 &, 167 &, 682 &,- 943 & $-1,926$ \\
x13 & 3,000 & 5,000 &,- 074 &,- 302 &,- 477 &,- 974 \\
x12 & 3,000 & 5,000 &,- 130 &,- 531 & $-1,006$ & $-2,054$ \\
x11 & 3,000 & 5,000 &, 080 &, 327 &,- 761 & $-1,554$ \\
Multivariate & & & & & $-5,417$ & $-1,009$ \\
\hline
\end{tabular}

Sumber: Data diolah, (2019)

\section{Evaluasi Atas Outliers}

Uji outlier multivariat dilakukan dengan menggunakan kriteria jarak Mahalanobis (Mahalanobis distance) Pada Tingkat $\mathrm{P}<0,001$. Jarak Mahalanobis dievaluasi dengan menggunakan $\chi^{2}$ pada derajat kebebasan. Berpedoman pada tabel distribusi $\chi^{2}$ (Henry, 2003) nilai batas berdasarkan Chi-Square dengan derajat kebebasan 129 atau $\chi^{2}(0.001,18)=42,31$ sehingga semua kasus yang mempunyai Mahalanobis distance lebih besar dari 42.31 dipandang sebagai outlier multivariat. Berdasar pada Tabel 21 menunjukkan bahwa tidak ada outlier multivariat pada data penelitian. 
Tabel 21. Mahalanobis D-Squared

\begin{tabular}{ccrr}
\hline Observation number & Mahalanobis d-squared & p1 & p2 \\
\hline 31 & 28,771 &, 051 &, 995 \\
82 & 26,957 &, 080 &, 998 \\
56 & 26,407 &, 091 &, 996 \\
98 & 25,986 &, 100 &, 992 \\
35 & 25,866 &, 103 &, 981 \\
20 & 25,498 &, 112 &, 973 \\
\hline
\end{tabular}

Sumber: Data diolah, (2019)

\section{Evaluasi Atas Multicollinearity dan Singularity}

Determinan yang benar-benar kecil mengindikasikan adanya multikolinearitas atau singularitas (Augusty, 2005). Sehingga data tidak dapat digunakan untu analisis yang sedang dilakukan. Berdasarkan hasil pengujian pada Tabel 22 didapat nilai determinat sampel of covarians matrix sebesar 1,96 dan nilai ini lebih besar dari nol, sehingga dapat dikatakan bahwa data penelitian ini tidak ditemukan indikasi adanya multikolinearitas atau singularitas.

\section{Tabel 22. Multicollinearity dan Singularity}

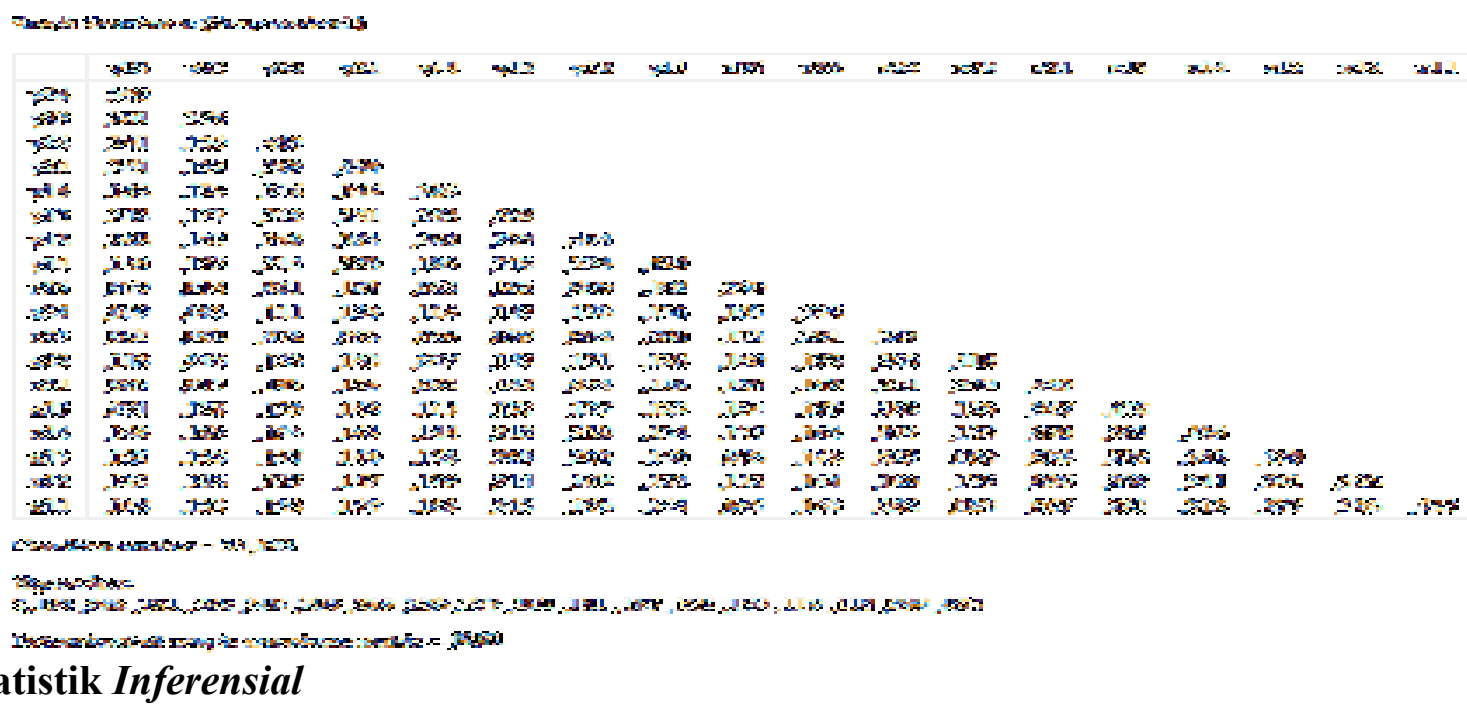

Statistik yang digunakan dalam penelitian sosial sebagai alat untuk menganalisis data untuk tujuan-tujuan eksplanasi ini disebut Statistik inferensial. Artinya model statistik ini hanya dipakai untuk tujuan-tujuan melakukan generalisasi sampel terhadap populasi, dengan kata lain bahwa penelitian bertujuan untuk menguji hipotesis penelitian. Maximum likelihood estimation method digunakan untuk teknik estimasi terhadap variabel-variabel penelitian dan teknik Confirmatory Factor Analysis dan teknik Full Structural Equetion Model digunakan untuk 
menganalisis estimasi secara bertahap (Bungin, 2011; Augusty, 2005).

\section{Teknik Confirmatory Factor Analysis}

Mengestimasi measurement model uji unidimensionalitas dari konstruk-konstruk eksogen dan endogen dan teknik ini akan mengkonfirmasi apakah variabel yang diamati dapat mencerminkan kaktor yang dianalisis. Pada teknik ini terdapat dua uji dasar yaitu uji kesesuaian model serta uji signifikansi bobot faktor.

\section{Uji Kesesuaian Model (Goodness of Fit Test)}

Pada tahap ini menguji unidimensionalitas dari variabel-variabel penelitian, dengan mengacu pada pendekatan yang telah tersaji pada Tabel 3.

Pengujian ini untuk melihat kesesuaian model hipotesis nol yang menyatakan tidak terdapat perbedaan antara matrix $\backslash k s$ kovarians sampel dengan matriks kovarian populasi yang diestimasikan. Hasil pengolahan data menunjukkan tingkat signifikansi uji hipotesis perbedaan adalah $\chi^{2}=129,012$ dengan probabilitas 0,483. Maka dapat dikatakan mengindikasikan nilai chisquare tidak signifikan sehingga hipotesis nol diterima.

Tabel 23 Menunjukkan uji kesesuaian persamaan model struktural menghasilkan sebuah tingkat penerimaan yang baik, meskipun nilai GFI dan AGFI berada sedikit diluar cut-off volume namun masih dalam batasan yang dapat diterima, sehingga persamaan model struktural layak dipergunakan.

Tabel 23. Hasil Uji Goodness Of Fit Full Structural Equation Model

\begin{tabular}{lccc}
\hline \multicolumn{1}{c}{ Indikator } & Cut-off Value & Hasil & Keterangan \\
\multicolumn{1}{c}{ Chi-Square } & Diharapkan kecil & $\mathbf{1 2 9 , 0 1 2}$ & Diharapkan $<\mathbf{1 2 4 , 3 4 2}$ \\
\hline Probabilitas & $\geq 0,05$ & 0,483 & Baik \\
Cmin/Df & $\leq 2,00$ & 1,000 & Baik \\
RMSEA & $\leq 0,08$ & 0,001 & Baik \\
GFI & $\geq 0,90$ & 0,895 & Moderat \\
AGFI & $\geq 0,90$ & 0,842 & Moderat \\
CFI & $\geq 0,95$ & 1,000 & Baik \\
TLI & $\geq 0,95$ & 1,000 & Baik \\
\hline
\end{tabular}

Sumber: Olahan data

Keterangan: Cut-off value $\chi^{2}(100,0.05)=124,3421$ (Supranto,2001:338) 


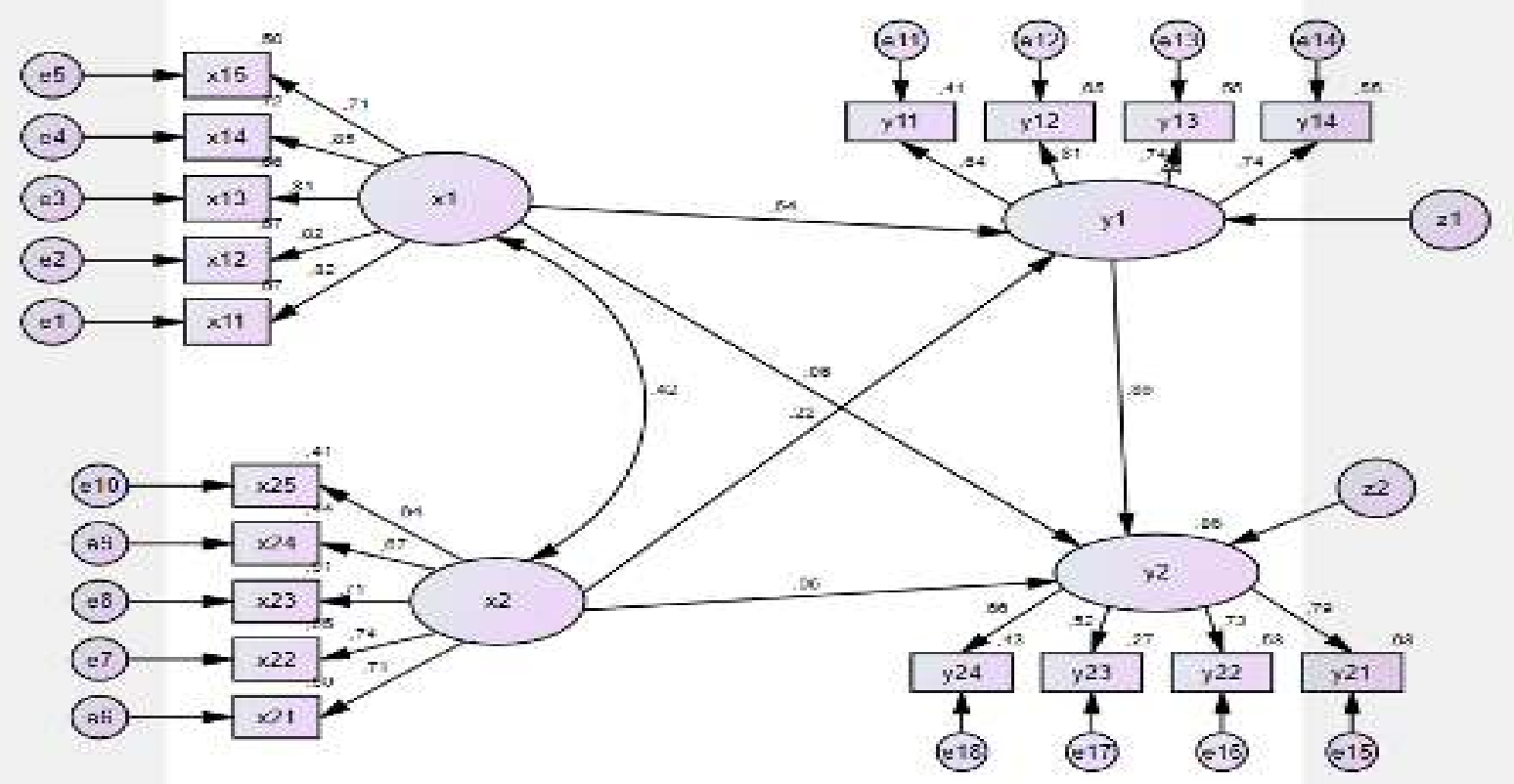

Sumber: data diolah peneliti

Gambar 2. Hasil Uji Structural Equation Modeling

Tabel 24. Hasil Uji Signifikansi Hubungan Kausalitas

\begin{tabular}{lcccc}
\hline \multicolumn{1}{c}{ Hubungan Kausalitas } & Estimasi & Critical Ratio & p \\
\hline Brand Image & $<---$ Kualitas Produk & 0.410 & 4.190 & 0.000 \\
Brand Image & $<--$ Komunikasi Marketing & 0.196 & 1.871 & 0.061 \\
Loyalitas Pelanggan & $<---$ Brand Image & 1.096 & 4.918 & 0.000 \\
\hline
\end{tabular}

Sumber: Olahan data

\section{Uji Kausalitas (Regression Test)}

Untuk pengujian hipotesis dapat dilihat kausalitas yang perlu dikembangkan dalam model ini, perlu diuji hipotesis nol yang menyatakan bahwa koefisien regresi antara hubungan adalah sama dengan nol melalui uji-t yang layak pada model regresi.

Pada tabel 22 mengindikasikan variabel kualitas produk mempunyai hubungan kasualitas yang signifikan dengan variabel brand image. Hal ini ditunjukkan dari nilai critical ratio sebesar 4,190 $(\mathrm{CR}>2)$ dan probabilitas 0,000 kurang dari 0,05. Namun diantara variabel komunikasi marketing dengan variabel brand image tidak terdapat hubungan kausalitas yang signifikan karena critical ratio kurang dari dua yaitu sebesar 1,871. Sedangkan variabel brand image mempunyai hubungan kausalitas yang signifikan dengan variabel loyalitas pelanggan, dapat dilihat dari nilai critical ratio sebesar 4,918 (CR>2).

\section{Pengujian Hipotesis}

Setelah uji goodness of fit dan uji signifikansi hubungan kausalitas, maka dapat

Pontjo Bambang dan Yesa Cahayaning Ramadhani: Pengaruh Kualitas Produk dan Komunikasi Marketing pada Brand Imange 
diperoleh hasil pengujian hipotesis sebagai berikut:

Tabel 25. Hasil Uji Hipotesis Penelitian

\begin{tabular}{lllll}
\hline Simbol & Hubungan Kausalitas & $\begin{array}{l}\text { Standar } \\
\text { Estimate }\end{array}$ & p & Keterangan \\
\hline H1 & Brand Image $\quad<---$ Kualitas Produk & 0.540 & 0.000 & Terbukti \\
H2 & Brand Image $<---$ Komunikasi Marketing & 0.224 & 0.061 & Tidak \\
H3 & Loyalitas Pelanggan $<---$ Brand Image & 0.860 & 0.000 & Terbukti \\
& & & & Terbukti \\
\hline
\end{tabular}

Sumber: Olahan data

Hipotesis pertama menyatakan kualitas produk mempengaruhi brand image terbukti sacara signifikan. Dapat dilihat dari nilai standardized estimate sebesar 0,540 dengan probabilitas $0,000(\mathrm{p}<0,05)$ menunjukkan kualitas produk memberikan pengaruh signifikan terhadap brand image sebesar $54 \%$.

Hipotesis kedua komunikasi marketing mempengaruhi brand image tidak terbukti secara signifikan. Nilai standardized estimate sebesar 0,224 dengan probabilitas 0,061 ( $>00,05)$ menunjukkan komunikasi marketing tidak memberikan pengaruh signifikan terhadap brand image sebesar $22,4 \%$.

Hipotesis ketiga menyatakan brand image mempengaruhi loyalitas pelanggan terbukti sacara signifikan. Dapat dilihat dari nilai standardized estimate sebesar 0,860 dengan probabilitas $0,000(\mathrm{p}<0,05)$ menunjukkan brand image memberikan pengaruh signifikan terhadap loyalitas pelanggan sebesar $86 \%$.

\section{Analisis Pengaruh Antar Variabel Penelitian}

Kekuatan pengaruh langsung dan pengaruh tidak langsung dari masing-masing konstruk. Pengaruh langsung ditandai dengan koefisien yang terdapat pada garis koefisien dengan anak panah satu ujung. Sedangkan pengaruh tidak langsung merupakan hasil perkalian koefisien awal dengan koefisien kontrol. Keberadaan variabel kontrol dalam hubungan multivariat sebagai perbandingan terhadap variabel bebas dan sebagai variabel penyebab terjadinya perubahan pada variabel tergantung (Bungin, 2011).

\section{Analisis Pengaruh Langsung}

Pengaruh langsung variabel kualitas produk (X1) dan komunikasi marketing (X2) daengan variabel brand image (Y1). Sedangkan pengaruh langsung variabel brand image (Y1) terhadap variabel loyalitas pelanggan (Y2). 
Tabel 26. Pengaruh Antar Variabel Penelitian

\begin{tabular}{lcc}
\hline \multicolumn{1}{c}{ Variabel } & Brand Image & Loyalitas Pelanggan \\
\hline Kualitas Produk & & \\
Komunikasi Marketing & 0.54 & 0.06 \\
Brand Image & 0.22 & 0.05 \\
\hline
\end{tabular}

Sumber: Data diolah

Tabel 26 mengindikasikan kualitas produk (X1) dan komunikasi marketing (X2) memberikan pengaruh langsung terhadap brand image (Y1) masing-masing sebesar 54\% dan $22 \%$. Sedangkan brand image (Y1) memberikan pengaruh langsung terhadap loyalitas pelanggan sebesar $86 \%$.

\section{Analisis Pengaruh Tidak Langsung}

Penelitian tidak langsung melibatkan variabel kualitas produk (X1) dengan loyalitas pelanggan (Y2), serta variabel komunikasi marketing (X2) dengan loyalitas pelanggan (Y2). Dalam hal ini variabel brand image (Y1) sebagai variabel kontrol.

Hasil perhitungan pada Tabel 26 mengindikasikan variabel kualitas produk (X1) memberikan pengaruh tidak langsung terhadap loyalitas pelanggan (Y2) sebesar 6\%. Sedangkan komunikasi marketing (X2) memberikan pengaruh tidak langsung terhadap loyalitas pelanggan (Y2) sebesar 5\%.

\section{KESIMPULAN DAN SARAN}

\section{Kesimpulan}

Berdasarkan hasil penelitian dan pembahasan yang telah disampaikan peneliti pada babbab terdahulu yang berpedoman pada hasil pengujian dengan menggunakan program SPSS dan AMOS, maka dapat peneliti simpulkan beberapa pernyataan sebagai berikut: Hipotesis pertama yang menyatakan bahwa kualitas produk mempengaruhi brand image dan terbukti secara signifikan. Nilai standardized estimate sebesar 0,540 dengan tingkat probabilitas 0,000 menunjukkan kualitas produk memberikan pengaruh yang signifikan terhadap penciptaan brand image sebesar 54\%, Hipotesis kedua yang menyatakan bahwa komunikasi marketing mempengaruhi brand image tedak terbukti secara signifikan. Nilai standardized estimate sebesar 0,224 menunjukkan komunikasi marketing memberikan pengaruh terhadap brand image sebesar $22,4 \%$, sedangkan nilai critical ratio kurang dari 2. Sehingga dapat dikatakan komunikasi marketing tidak berpengaruh signifikan terhadap brand image. Hipotesis ketiga yang menyatakan 
bahwa brand image mempengaruhi loyalitas pelanggan terbukti secara signifikan. Nilai standardized estimate sebesar 0,860 dengan tingkat probabilitas 0,000 menunjukkan brand image memberikan pengaruh signifikan terhadap loyalitas pelanggan produk sarung sebesar $86 \%$.

\section{Saran}

Berdasarkan beberapa simpulan yang telah dikemukakan diatas, maka peneliti berkeinginan untuk memberikan bebebrapa saran sebagai berikut: Pertama sebaiknya pihak produsen sarung lebih mengupayakan komunikasi marketing dengan lebih intens atau sering pada tayangan baik televisi maupun media cetak, promosi penjualan sarung dapat dilakukan bersamaan dengan even - even tertentu. Karena strategi komunikasi marketing seperti ini akan menjadi diferensiasi tersendiri saat strategi komunikasi merek-merek pesaing masih berkutata pada segmen-segmen tertentu. Kedua sebaiknya pihak produsen lebih gencar lagi menciptakan citra merek yang positif dengan kualitas produk dan berbagai upaya komunikasi marketing yang efektif, sehingga diharapkan dapat meningkatkan pembelian pada produk mereka. Oleh karena tanpa disadari merek-merek produk sarung hingga kini masih bersaing ketat untuk menjadi produk terbaik.

\section{REFERENSI}

Anshori, M., \& Irawati, S. (2009). Metodologi Penelitian Kuantitatif. Surabaya: Airlangga University Press.

Augusty, F. (2005). Structural Equation Modeling (3rd ed.). Semarang: Badan Penerbit Universitas Diponegoro.

Bungin, B. (2011). Penelitian Kualitatif: Komunikasi, Ekonomi, Kebijakan Publik, dan Ilmu Sosial Lainnya. In Kencana.

Evergrandes. (2014). Penjualan Sarung Tenun Indonesia 2014 Meningkat. Retrieved from https://www.google.co.id/amp/s/jualsarung123.wordpress.com/2014/07/27/penjualansarung-tenun-indonesia-2014-meningkat/amp/ diakses tanggal 31 Januari 2019

Ghozali, I. (2013). Aplikasi Analisis Multivariate dengan Program IBM dan SPSS 21. In Aplikasi Analisis Multivariate dengan Pogram iIBM https://doi.org/10.1126/science.1158668

Hasan, A. (2018). Marketing. Yogyakarta: MedPress (Anggota IKAPI).

Henry, S. (2003). Manajemen Sumber Daya Manusia In Manajemen Sumber Daya Manusia. In Edisi Revisi Jakarta: Bumi Aksara.

Khadafi, A. (2017). Kasta Sarung dari Premium Hingga Kluyur. Retrieved from tirto.id website: https://irto.id/kasta-sarung-dari-premium-hingga-kluyur-ckPC

Kuncoro, mudrajad. (2010). Metode kuantitatif: teori dan aplikasi untuk bisnis dan ekonomi. System.

Susanto, Monica. 2008. Pengaruh Loyalitas dan Sikap Konsumen pada Produk coklat terhadap Tingkat Keluhan Kesehatan Gigi serta Dampaknya terhadap Keputusan Pembelian Produk Kesehatan Gigi di Surabaya. Universitas Widya Kartika. Surabaya. 
Sugito, C. 2009. Pengaruh Kualitas Produk dan Komunikasi Marketing pada Brand Image serta Dampaknya terhadap loyalitas Pelanggan Studi pada Konsumen Produk Pembalut Wanita di Universitas Widya Kartika. Surabaya.

Temporal, P. 2001. Branding In Asia (Membangun Merek di Asia). Penerbit Interaksa. Batam Center.

http://www.topbrand-award.com/top-brand-survey/survey-result/top_brand_index_2018_fase 2 diakses tanggal 31 Januari 2019 